\title{
A STUDY ON THE STANDARDIZATION PARAMETERS OF BAUHINIA VARIEGATA
}

\author{
PRAGATI KHARE ${ }^{1 *}$, KAMAL KISHORE ${ }^{2}$, DINESH KUMAR SHARMA ${ }^{3}$
}

${ }^{1}$ Department of Pharmacy, Shri Ram Murti Smarak, C.E.T., Bareilly, Uttar Pradesh, India. ${ }^{2}$ Department of Pharmacy, M.J.P. Rohilkhand University, Bareilly, Uttar Pradesh, India. ${ }^{3}$ Department of Pharmacy, Devsthali Vidyapeeth College of Pharmacy, Rudrapur, Uttarkhand, India. Email: pragatikhare10@gmail.com

Received: 22 November 2016, Revised and Accepted: 31 January 2017

\section{ABSTRACT}

Objective: In today's scenario, the herbal medicines are much efficient for the treatment of various disorders as they have minimal side effects in comparison to the allopathic medicines. Bauhinia variegata L. (Mountain Ebony), commonly called Kachnar, belongs to the family Leguminosae. It is a medium-sized tree, mostly found at an altitude of $1300 \mathrm{~m}$ in the Himalayas. The objectives of the present study are to investigate various pharmacognostic, phytochemical analysis, and pharmacological properties of B. variegata.

Methods: The powdered drug was used for estimating the loss on drying, ash values, fluorescence studies, chemical tests, and extractive values. Macroscopic and microscopic studies were also performed.

Results: The leaf microscopy revealed the presence of upper and lower epidermis, palisade tissue, well-developed vascular bundle. The fluorescence characteristics of leaf powder were studied both in visible light and ultraviolet light (254 $\mathrm{nm}$ and $365 \mathrm{~nm}$ ) after treatment with various reagents. Kachnar is composed of carbohydrates, tannins, alkaloids, flavonoids, amino acid. It was reported that the total ash value was $8.15 \%$. The acid insoluble ash value was $5.5 \%$.

Conclusion: The main pharmacological activities of B. variegata are anthelmintic, antiulcer, antitumor, antimicrobial, antidiabetic, anti-inflammatory, antigoitrogenic, and hepatoprotective. The present investigation provides the information on its pharmacognostic, phytochemical analysis, and pharmacological properties.

Keywords: Flavonoids, Kachnar, Alkaloids, Antioxidant, Leguminosae.

(C) 2017 The Authors. Published by Innovare Academic Sciences Pvt Ltd. This is an open access article under the CC BY license (http://creativecommons. org/licenses/by/4. 0/) DOI: http://dx.doi.org/10.22159/ajpcr.2017.v10i4.16295

\section{INTRODUCTION}

Bauhinia variegata belongs to family leguminosae (caesalpinioideae) and is commonly known as Kachnar (Hindi), Mountain Ebony (English), and Rakta kanchan (Marathi). It is a medium-sized, deciduous tree found throughout India, mostly at $1800 \mathrm{~m}$ in the Himalayas. The genus Bauhinia includes about 600 species including shrubs, trees, and vines. It is mostly planted as an ornamental plant. It grows throughout India and China. It is a crucial greenhouse species of the Himalayas [1].

B. variegata Linn. is used for curing bronchitis, leprosy, inflammation, bacterial infection, diarrhea, dysentery, skin disease, intestinal worms, wounds, ulcer, fungal infection, ulcers, and tumors [2-4]. The stem bark is used as astringent, alliterative, antidiabetic, antitumor, tonic and anthelmintic, obesity, and washing ulcers [2,4-6].

The flowers of $B$. variegata are hermaphrodite. The color of the petals is purple/white/yellow. The shape of petal is obovate with $4-6 \mathrm{~cm}$ length and 2-3 cm width. It grows well in sandy, loamy, and clay soils [7].

The stem bark of $B$. variegata is composed of kaempferol-3glucoside, lupeol, 5,7 dihydroxy and 5,7 dimethoxy flavanone-4-0- $\alpha-\mathrm{L}$ rhamnopyrosyl- $\beta$-D-glycopyranosides, and beta sitosterol [8].

Taxonomical classification [9]

\begin{tabular}{ll}
\hline Kingdom & Plantae \\
\hline Subdivision & Spermatophyta \\
Division & Magnoliophyta \\
Class & Magnoliopsida \\
Subclass & Rosidae \\
\hline
\end{tabular}

\begin{tabular}{ll}
\hline Order & Fabales \\
Family & Caesalpiniaceae \\
Genus & Bauhinia \\
Species & Variegata \\
\hline
\end{tabular}

\section{Macroscopic characters}

The bark is light brownish-gray, smooth to slightly fissured, and scaly. Leaves have minute stipules $1-2 \mathrm{~mm}, 3-4 \mathrm{~cm}$; lamina broadly ovate to circular, often broader than long, 6-16 cm diameter; 11-13 nerved. Flower clusters (racemes) are unbranched at ends of twigs. Pods are dehiscent, strap-shaped, $20-30$ by $2-25 \mathrm{~cm}$; long, hard, flat with $10-15$ seeds [1].

\section{METHODS}

The leaves of B. variegata L. were collected from the College Campus of Shri Ram Murti Smarak (College of Engineering and Technology), Bareilly (Uttar Pradesh) and identified (specimen number- RU/PS/2016/415) by Prof. A.K. Jaitly, Head, Department of Plant Science, Mahatma Jyotiba Phule Rohilkhand University, Bareilly, Uttar Pradesh.

Powdered drug was used for moisture content, ash values, swelling index, and fluorescence studies were carried out by treating $0.5 \mathrm{~g}$ of powdered drug with different reagents and observation in color was made in visible light, ultraviolet (UV) light of short (254 nm) and long wavelength (365 nm) under UV chamber. Photomicrography was done using Olympus C7070 camera [10].

\section{RESULTS AND DISCUSSION}

\section{Microscopical examination of leaf}

The upper and lower epidermis is covered by thin cuticle. Palisade tissue is two layered and the cells are columnar which are loosely arranged and it has well-developed vascular bundle with xylem and 


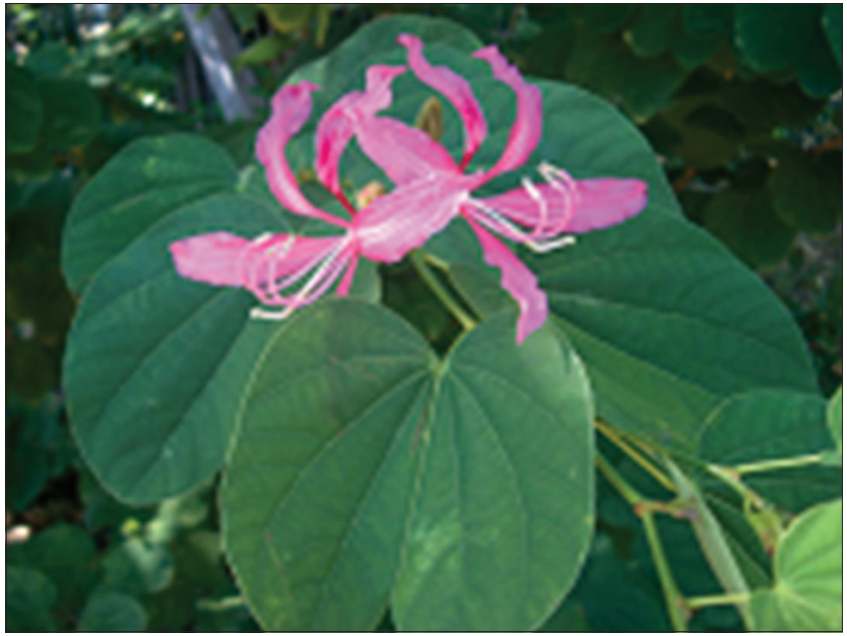

Fig. 1: Leaves and flowers of Bauhinia variegate phloem. Most of the cells have calcium oxalate crystals. The vascular bundles are seen to be surrounded by sclerenchymatous tissue.

\section{Pharmacognostic evaluation of the plant}

The plant material was used for quantitative determination of physicochemical values. Ash values, loss on drying, and extractive values were estimated.

\section{Phytochemical screening}

The dried leaves were powdered and extracted with petroleum ether, chloroform, ethanol, and water in soxhlet apparatus. The percentage yield was analyzed. The phytochemical tests were performed for the estimation of alkaloids, glycosides, flavonoids, and tannins in various plant extracts and resulted in the presence of carbohydrates, gums, proteins, alkaloid, saponins, flavonoids, and tannins and results are given in Table 1.

\section{Fluorescent studies of powder drugs}

The fluorescence characteristics of leaf powder were studied both in visible light and UV light (254 nm and $365 \mathrm{~nm}$ ) after treatment with various reagents and is represented in Table 2 [11-13].

Table 1: Chemical tests

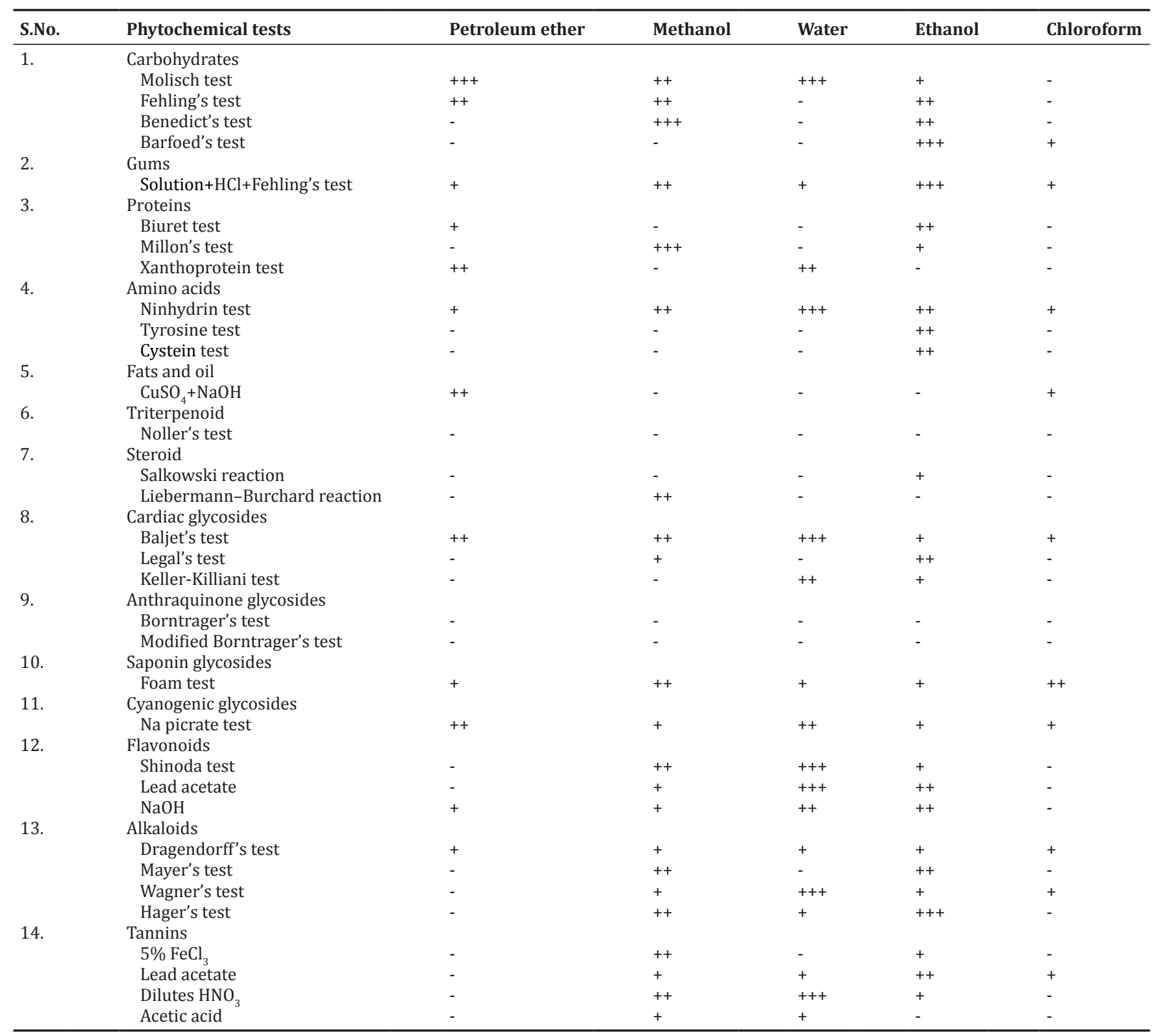

+: Trace, ++: Present, +++: Excess, - Absent 
Table 2: Fluorescence activity of $B$, variegata Linn. leaves

\begin{tabular}{|c|c|c|c|c|}
\hline \multirow[t]{2}{*}{ S.No. } & \multirow[t]{2}{*}{ Material/treatment } & \multicolumn{3}{|c|}{ Observation under UV cabinet } \\
\hline & & $\begin{array}{l}\text { Visible } \\
\text { light }\end{array}$ & $\begin{array}{l}\text { Short UV } \\
254 \mathrm{~nm}\end{array}$ & $\begin{array}{l}\text { Long UV } \\
365 \mathrm{~nm}\end{array}$ \\
\hline 1. & Drug powder as such & $\begin{array}{l}\text { Light } \\
\text { green }\end{array}$ & $\begin{array}{l}\text { Fluorescent } \\
\text { green }\end{array}$ & $\begin{array}{l}\text { Light } \\
\text { brown }\end{array}$ \\
\hline 2. & $\begin{array}{l}\text { Drug powder rubbed } \\
\text { on Whatman filter } \\
\text { paper }\end{array}$ & $\begin{array}{l}\text { Dark } \\
\text { green }\end{array}$ & Green & Black \\
\hline 3. & $\begin{array}{l}\text { Powder treated with } \\
1 \text { molar } \mathrm{NaOH} \text { in } \\
\text { water }\end{array}$ & $\begin{array}{l}\text { Light } \\
\text { green }\end{array}$ & Green & $\begin{array}{l}\text { Dark } \\
\text { green }\end{array}$ \\
\hline 4. & $\begin{array}{l}\text { Powder treated with } \\
\text { pet ether }\end{array}$ & $\begin{array}{l}\text { Light } \\
\text { green }\end{array}$ & Green & $\begin{array}{l}\text { Light } \\
\text { brown }\end{array}$ \\
\hline 5. & $\begin{array}{l}\text { Powder treated with } \\
5 \% \text { iodine }\end{array}$ & $\begin{array}{l}\text { Light } \\
\text { brown }\end{array}$ & Light green & $\begin{array}{l}\text { Dark } \\
\text { green }\end{array}$ \\
\hline 6. & $\begin{array}{l}\text { Powder treated with } \\
5 \% \mathrm{FeCl}_{3}\end{array}$ & $\begin{array}{l}\text { Dark } \\
\text { brown }\end{array}$ & Green & $\begin{array}{l}\text { Dark } \\
\text { green }\end{array}$ \\
\hline 7. & $\begin{array}{l}\text { Powder treated with } \\
\text { diluted ammonia }\end{array}$ & $\begin{array}{l}\text { Light } \\
\text { green }\end{array}$ & $\begin{array}{l}\text { Fluorescent } \\
\text { green }\end{array}$ & Brown \\
\hline 8. & $\begin{array}{l}\text { Powder treated with } \\
\text { methanol }\end{array}$ & $\begin{array}{l}\text { Dark } \\
\text { green }\end{array}$ & Green & Brown \\
\hline 9. & $\begin{array}{l}\text { Powder treated with } \\
1 \mathrm{M} \mathrm{H}_{2} \mathrm{SO}_{4}\end{array}$ & $\begin{array}{l}\text { Light } \\
\text { green }\end{array}$ & Light green & Brown \\
\hline 10. & $\begin{array}{l}\text { Powder treated with } \\
\text { picric acid }\end{array}$ & $\begin{array}{l}\text { Light } \\
\text { green }\end{array}$ & Green & $\begin{array}{l}\text { Dark } \\
\text { green }\end{array}$ \\
\hline 11. & $\begin{array}{l}\text { Powder treated with } \\
\text { chloroform }\end{array}$ & $\begin{array}{l}\text { Light } \\
\text { green }\end{array}$ & Light green & Brown \\
\hline
\end{tabular}

B. variegata: Bauhinia variegata, UV: Ultraviolet

\section{Table 3: Physiochemical parameters}

\begin{tabular}{lll}
\hline S.No. & Parameters & Values (\%) \\
\hline 1. & Total ash value & 8.15 \\
2. & Water insoluble ash value & 6.50 \\
3. & Water soluble ash value & 2.25 \\
4. & Acid insoluble ash value & 5.50 \\
5. & Loss on drying & 6.66 \\
\hline
\end{tabular}

The physiochemical parameters of leaf of B. variegata Linn. are tabulated in Table 3 . The loss on drying at $105^{\circ} \mathrm{C}$ in leaf was found to be $6.66 \%$. Total ash value of leaf represents minerals and earthy materials attached in the plant material. It was reported that the total ash value was $8.15 \%$. The acid insoluble ash value was $5.5 \%$. The water soluble ash value represents the presence of acids, sugar, and inorganic compounds and was found to be $2.25 \%$. The results are given in Table 3.

\section{CONCLUSIONS}

The phytochemical and physicochemical investigations of $B$. variegata were performed in this study. These parameters are necessary for the identification of drugs. The presence of various chemical constituents in B. variegata may be a potential cause of treatment of various disorders. The quality of the plant can be estimated by determining the physical parameters. These investigations are of great importance for carrying out the revalidation and estimation of its other pharmacological activities. It was concluded from the phytochemical study that the ethanolic extract contains flavonoids, glycosides, carbohydrates, and tannins which are responsible for various pharmacological activities such as anti-inflammatory, chemoprotective activity, antioxidant, antidiabetic, antianxiety, and antidepressant.

\section{ACKNOWLEDGMENTS}

We are thankful to the Management of Department of Pharmacy, Shri Ram Murti Smarak, C.E.T., Bareilly, Uttar Pradesh, India, for providing

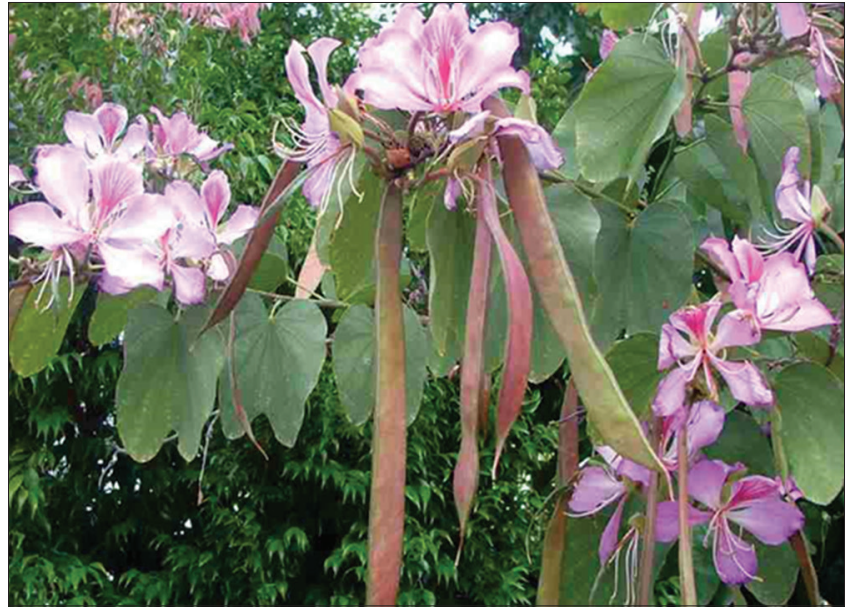

Fig. 2: Pods, flowers, and leaves of Bauhinia variegata

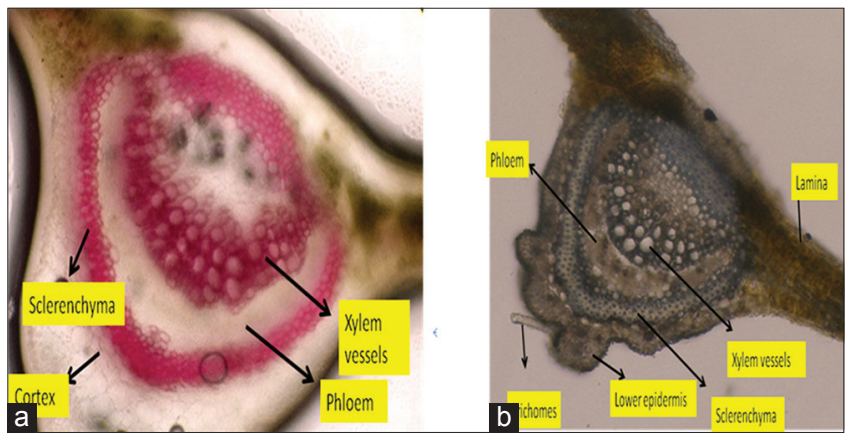

Fig. 3: (a and b) T.S. of leaf of Bauhinia variegata Linn.

chemicals and other infrastructure for doing this research work. The work is dedicated to my guide and coguide.

\section{REFERENCES}

1. Deswal G, Arora K. Ethnobotany and phytopharmacology of Bauhinia variegata. Int J Pharm Drug Anal 2015;3(9):261-3.

2. Prashar Y, Kumar AS. Antiobesity activity of Bauhinia variegata Linn. in high fat diet induced obesity in female rats. Pharmacologyonline 2010;2:1008-16.

3. Yadava RN, Reddy VM. Anti-inflammatory activity of a novel flavonol glycoside from the Bauhinia variegata Linn. Nat Prod Res 2003;17(3):165-9.

4. Sinha K, Verma A. Evaluation of antimicrobial and anticancer activities of methanol extract of in vivo and in vitro grown Bauhinia variegata L. Int Res J Biol Sci 2012;1(6):26-30.

5. Ambasta SP. The Wealth of India, Raw Materials. New Delhi: CSIR; 1998. p. 56-7.

6. Rajkapoor B, Jayakar B, Murugesh N. Antitumour activity of Bauhinia variegata on Dalton's ascitic lymphoma. J Ethnopharmacol 2003;89(1):107-9.

7. Bairagi SM, Aher AA, Nimase PK. In vitro anthelmintic activity of Bauhinia variegata barks (Leguminosae). Int J Pharm Pharm Sci 2012;4(3):672-4

8. Marasani A. Hepatoprotective activity of Bauhinia variegata against isoniazid and rifampicin-induced toxicity in experimental rats. Int $\mathrm{J}$ Pharm Pharm Sci 2014;6(4):177-81.

9. Sudheerkumar K, Seetaramswamy S, Babu AK, Kumar PK. Phytopharmacognostical and isolation of chemical constituents from Bauhinia variegata leaf extract. J Pharmacogn Phytochem 2015;1(2):189-91.

10. Sunita P, Jha S, Pattanayak SP. Anti-inflammatory and in-vivo antioxidant activities of Cressa cretica Linn. A halophytic plant. Middle East J Sci Res 2011;8(1):129-40.

11. Prasad V, Kadam R, Deoda S, Rakesh S. Pharmacognostic, phytochemical and physiochemical studies of Mimusops elengi Linn stem bark (Sapotaceae). Pharm Lett 2012;4(2):607-13. 
12. Arulanandraj N, Gopal V. Phytochemical screening of roots extracts of Marva (Maerua oblongifolia). Int J Univ Pharm Life Sci 2011;1(2):282-93.
13. Katara A, Pradhan CK, Tyagi AK, Singh P. Phytochemical investigation and antimicrobial activity of Leucas cephalotes Roth, Spreng whole herb. Pharm Chem 2010;2(4):284-96. 